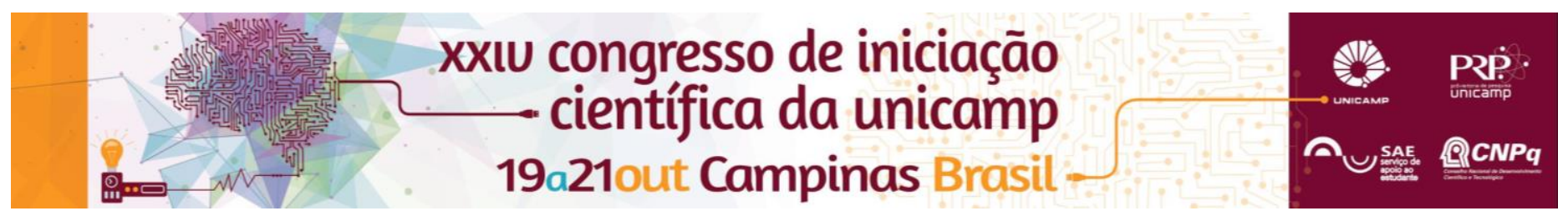

\title{
EVALUATION OF THE PREVALENCE OF SKIN HYPERPIGMENTATION IN HOSPITALIZED PATIENTS IN THE CLINICAL HOSPITAL OF UNIVERSITY OF CAMPINAS (UNICAMP) IN TREATMENT WITH POLIMYXIN B.
}

\section{Isabela R. Gouvêa*, Karen P. H. Mattos and Patricia Moriel.}

\begin{abstract}
It was done a cohort study in order to evaluate the acquired skin hyperpigmentation following intravenous polymyxin B treatment. Patients were followed throughout the course of the treatment, and changes in skin tone were captured by a digital camera and measured using a colorimetric scale. It was observed that $7,5 \%$ of the patients manifested this adverse reaction, with $71,4 \%$ of them being classified as presenting the skin tone brown or black. Dermoscopy suggested that the pigment is melanin.
\end{abstract}

\section{Key words:}

Skin Hyperpigmentation; Polymyxin B; Melanin;

\section{Introduction}

Polymyxins represent a class of antimicrobials widely used until the decade of 1960 - when it got into disuse, because of its toxicity. However, the emerging growth of infections caused by multiresistant gram-negative bacteria led this class to be reintroduced in the clinical practice, due to its low rate of bacterial resistance ${ }^{1}$. The main adverse reactions related to polymyxins are nephrotoxicity and neurotoxicity. Nevertheless, in clinical practice it was observed that some patients have developed skin hyperpigmentation $(\mathrm{SH})$ restricted to head and neck. ${ }^{2}$ This study aimed to better characterize the $\mathrm{SH}$ as well as the risk factors associated with its onset.

\section{Results and Discussion}

The incidence of the reaction was $7,5 \%$ (14 patients labeled $\mathrm{SH}+$ group). $71,4 \%$ of these patients had their skin tone classified as brown or black. On average, the pigmentary outcome was remarkable on the 3th day of treatment. The light exposure showed no effect in the occurrence of the reaction. According to Naranjo algorithm ${ }^{3}$, causality between $\mathrm{SH}$ and treatment with polymyxin $B$ recorded 5 points, being considered as probable. The color observed in dermoscopy suggested the presence of melanin in the epidermis.
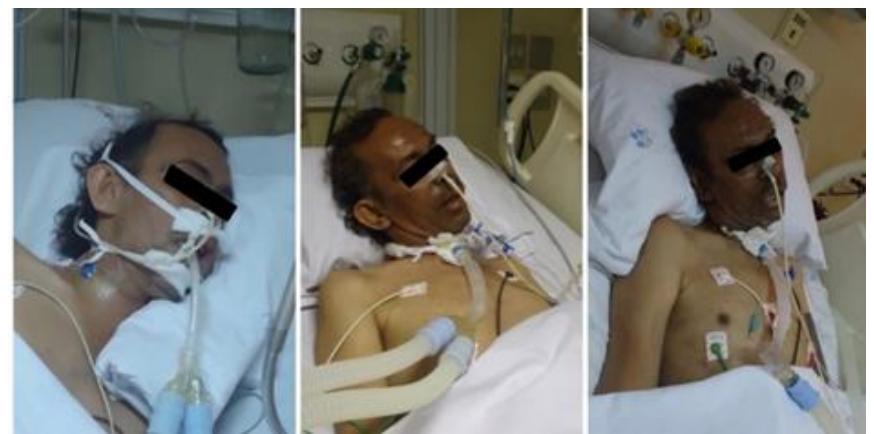

Image 1. SH development over 12 days under polymyxin $B$ treatment.
Chart 1. Comparison between groups $\mathrm{SH}+$ and $\mathrm{SH}-$.

\begin{tabular}{|l|c|c|}
\hline & $\mathrm{SH}+$ & $\mathrm{SH}-$ \\
\hline Patients Included & $14(7,5 \%)$ & $172(92,5 \%)$ \\
\hline Average age (years) & $53,6 \pm 15,7$ & $53,1 \pm 17,1$ \\
\hline Caucasian & $2(14,3 \%)$ & $119(69,2 \%)$ \\
\hline Brown & $6(42,8 \%)$ & $38(22,1 \%)$ \\
\hline Black & $4(28,6 \%)$ & $13(7,5 \%)$ \\
\hline Indigenous & $2(14,3 \%)$ & $1(0,6 \%)$ \\
\hline Asiatic & $0(0,0 \%)$ & $1(0,6 \%)$ \\
\hline
\end{tabular}

\section{Conclusions}

In sum, it was observed that $7,5 \%$ of patients had characteristic $\mathrm{SH}$, affecting their head and neck. Patients with skin tone classified as brown or black are more likely to manifest this adverse reaction. Dermoscopy suggested that the pigment is melanin. Further study should be conducted in order to better understand and elucidate the development process of this reaction.

\section{Acknowledgement}

To CNPq, for the financial support.

\footnotetext{
${ }^{1}$ Zavascki AP, Li J. Intravenous colistimethate for multidrug-resistant Gramnegative bacteria. Lancet Infect Dis. 2008; 8: 403-5.

${ }^{2}$ Law KS, Chan LG. Polymyxin B induced generalized skin hyperpigmentation in infants. Journal of Pediatric Sciences. 2014; 6:e 215.

${ }^{3}$ Naranjo, C.A.; Busto, U.; Sellers, E.M.; Sandor, P.; Ruiz, I.; Roberts, E.A.; Janeck, E.; Domecq, C.; Greenblett, D.J. A method for estimating the probability of adverse drug reactions. Clin. Pharmacol. Ther., 1981. 30(2):239245 .
} 